\title{
Lagochilascaris minor: antibody production in experimentally infected mice
}

\author{
Lagochilascaris minor: produção de anticorpos em camundongos \\ experimentalmente infectados
}

\author{
Mariana Félix de Souza Prudente ${ }^{1}$, Adriana de Moraes Costa Crespo ${ }^{1}$ \\ and Mara Silvia Carvalhaes ${ }^{1}$
}

\begin{abstract}
Lagochilascaris minor is the causative agent of lagochilascariosis, a disease that affects the neck region and causes festering abscesses, with eggs, adult parasites and L3/L4 larvae within the purulent exudates. Today, mice are considered to be intermediate hosts for the parasite. C57BL/6 mice produce immunoglobulin IgM, IgA and IgG against the crude extract of the parasite; on the other hand, antibodies produced against the secreted/ excreted antigens of Lagochilascaris minor present lower levels of IgM, IgA and IgG. This is the first description of antibody detection against different antigens of Lagochilascaris minor.
\end{abstract}

Key-words: Lagochilascaris minor. Immunoglobulin G. Immunoglobulin A. Immunoglobulin M. Serology.

\section{RESUMO}

Lagochilascaris minor é o agente etiológico da lagochilascariose, uma doença que afeta a região do pescoço causando abscessos exudativos com presença de ovos, parasitos adultos e larvas nos de exudatos purulentos. Hoje em dia, camundongos são considerados os hospedeiros intermediários para o parasita. Camundongos C57BL/6 produziram imunoglobulinas IgM, IgA e IgG contra o extrato bruto do parasita; por outro lado, anticorpos produzidos contra os antígenos secretados/excretados de Lagochilascaris minor apresentaram níveis mais baixos de IgM, IgA e IgG. Esta é a primeira descrição da detecção de anticorpos contra diferentes antígenos de Lagochilascaris minor.

Palavras-chaves: Lagochilascaris minor. Imunoglobulina G. Imunoglobulina A. Imunoglobulina M. Sorologia.

Human lagochilascariosis, caused by Lagochilascaris minor, is not yet a public health problem, but it is considered to be an emerging helminthosis. It is limited to the neotropical area (Mexico to Brazil), but infected cats have been found in Uruguay ${ }^{11}$. It is prevalent among individuals of the lowest socioeconomic class, notably in rural areas ${ }^{4}$. The genus Lagochilascaris includes five species: Lagochilascaris minor, Lagochilascaris major, Lagochilascaris buckleyi, Lagochilascaris turgida and Lagochilascaris sprenti ${ }^{5}$. Of these, Lagochilascaris minor is the most important from a medical standpoint, since it is the etiological agent for human lagochilascariosis in South America ${ }^{14}$.

Cases of infection have been reported in persons of both sexes. The lesions are usually chronic, affecting the neck and head tissues with abscess formation. Sometimes the parasite invades the pulmonary tissue and central nervous system, in fatal cases.

1. Department of Microbiology, Immunology, Parasitology and Pathology, Institute of Tropical Pathology and Public Health, Federal University of Goiás, Goiânia, GO, Brazil

Financial support: This work was financed by FAPEG (grant 02/2007).

Address to: Dra. Mara Silvia Carvalhaes. Immunology Sector- Laboratory 328/DMIPP/ IPTSP/UFG. Postal Box 1031, 74001-970, Goiânia, GO, Brazil.

Tel: 5562 3209-6109; Fax: 5562 3521-1839

e-mail: msilvia@iptsp.ufg.br

Received in 15/10/2008

Accepted in 29/04/2008
Lagochilascaris minor lesions frequently contain different stages of the parasite (eggs, larvae and adult worms), thereby indicating autoinfection and favoring the development of chronic disease ${ }^{4}$.

The extraordinary capacity of Lagochilascaris minor to migrate across different human tissues can be also observed in animal models of the disease, such as in mice and cats. In mice that are orally inoculated with infective parasite eggs, hatched larvae can be observed migrating in the intestinal tract. Third-stage larvae (L3) migrate through the intestinal mucosa to reach vessels and hepatic parenchyma and disseminate to other tissues such as lungs, skeletal muscles and subcutaneous tissues. In cats that eat infected mice, L3 migrate through the esophagus, pharynx, trachea and cervical lymph nodes ${ }^{13} 14$. In other rodents, such as Callomys porcellus and Callomys callosus, hatching of $\mathrm{L} 3$ has been observed, and eggs of Lagochilascaris minor have been observed 6-12 hours after inoculation, in the small intestine. L3 migration to the liver and lungs has been observed 24 hours after inoculation, while migration to skeletal muscles and subcutaneous tissues has been detected 13 days after infection. Granulomatous nodules containing encysted L 3 have been found 38 days after infection, in subcutaneous and adipose tissues, skeletal muscles, lungs, liver, tonsils, eyeballs and mesentery in experimentally inoculated rodents. Five specimens of Drasypocta agout $i$ were found to present several small nodules containing encysted L 3 larva 
surrounded by granulomatous inflammatory reaction, with visible nodule dissemination through the host tissues (subcutaneous, muscle, adipose, pulmonary and mesenteric tissues). Migration patterns and L3 encystment have been found to be similar in all wild rodents and similar to the infection observed in mice ${ }^{7}$.

In view of the above, we consider it to be of major importance to develop serological methods for detecting infection in mice, and perhaps in wild rodents in nature.

\section{MATERIAL AND METHODS}

Animals and parasites. Six to eight-week-old C57BL/6 mice were kindly supplied by the vivarium of the Federal University of Goiás. They were kept supplied with food and water ad libitum and handled according to the local regulations. The Research Ethics Committee of the Federal University of Goiás approved the study protocols.

Parasite eggs were collected from feces of Felis domesticus that had been experimentally infected with a human isolate of Lagochilascaris minor. The feces from these infected animals were subjected to Hoffman's method, kept in culture in formalin solution (1\%) at room temperature for 30 days. After infective eggs containing third-stage larvae had developed, the cultures were subjected to Faust's method in order to achieve the best recovery of eggs free from fecal debris ${ }^{6}$. The egg suspensions thus obtained were exhaustively washed with phosphate buffered saline and the eggs were counted on microscope slides. The final concentration was adjusted to $10^{4} \mathrm{eggs} / \mathrm{ml}$.

Experimental infection design. Fifty-four C57BL/6 mice were orally inoculated with a suspension of $10^{3} \pm 200$ Lagochilascaris worms. At different time points (from 15 to 210 days after infection), six infected mice (three male and three female) were sacrificed and subjected to necropsy in order to collect larvae (to prepare antigens) and blood (to separate serum out, for antibody determination). Eighteen uninfected control C57BL/6 mice were inoculated orally with saline. On different days after the beginning of infection, one male and one female were sacrificed to serve as controls for the serological tests.

Antibody detection. For crude extract antigen preparation, parasite larvae obtained from subcutaneous and skeletal nodules in infected mice were washed thoroughly in sterile $0.85 \% \mathrm{NaCl}$, and were broken down in a TK8-Labortechnik tissue breaker using $0.1 \mathrm{M}$ Tris ( $\mathrm{pH} 7.5$ ) containing a cocktail of protease inhibitors, all from Sigma (1mM phenylmethylsulphonyl fluoride (PMSF); 1mM ethylenediamine tetraacetic acid (EDTA); 5mM leupeptin and $2.5 \mathrm{mM}$ aprotinin). For secreted/excreted antigen preparation, the parasite larvae were washed thoroughly in sterile $0.85 \% \mathrm{NaCl}$, incubated overnight at $37^{\circ} \mathrm{C}$ in $0.1 \mathrm{M}$ Tris (pH 7.5) and, after collecting the fluid phase, a cocktail of protease inhibitors was added. The protein concentration was determined by the bicinchoninic acid method (Pearce), in accordance with the manufacturer's instructions. To detected anti-Lagochilascaris minor antibodies, microtiter ELISA plates (Costar) were coated with antigen $(50 \mu \mathrm{g} / \mathrm{ml})$ and serum was used diluted 1/100 (for IgG, IgM and IgA determination). Anti-mouse IgG, IgM and IgA antibodies conjugated with peroxidase were purchased from the
Laboratory of Generic Chemistry (LGC). Antibody binding was detected by using ortho-phenylenediamine and hydrogen peroxide as the chromogen and substrate, respectively. The optimal dilution for the reagents was established in our laboratory. The plates were read at $492 \mathrm{~nm}$ on a Thermo Labsystems Multiskan device. The cutoff value was determined by taking the mean optical density of twenty control subjects plus three standard deviations.

Statistical analysis. The results were expressed as means and standard deviations. Data from pairs of groups were analyzed using the Mann-Whitney U test; and data from multiple groups were analyzed using the ANOVA test followed by a multiple comparison test (Dunn's test) (Prism 4.0 software).

\section{RESULTS}

The kinetics of the specific Lagochilascaris minor antibody levels for each immunoglobulin (Ig) isotype are shown in Figures 1, 2 and 3. All optical densities above the cutoff were statistically significant, in relation to the optical densities presented by the serum of non-infected animals $(p \leq 0.05)$. The results from male and female mice were taken together because there was

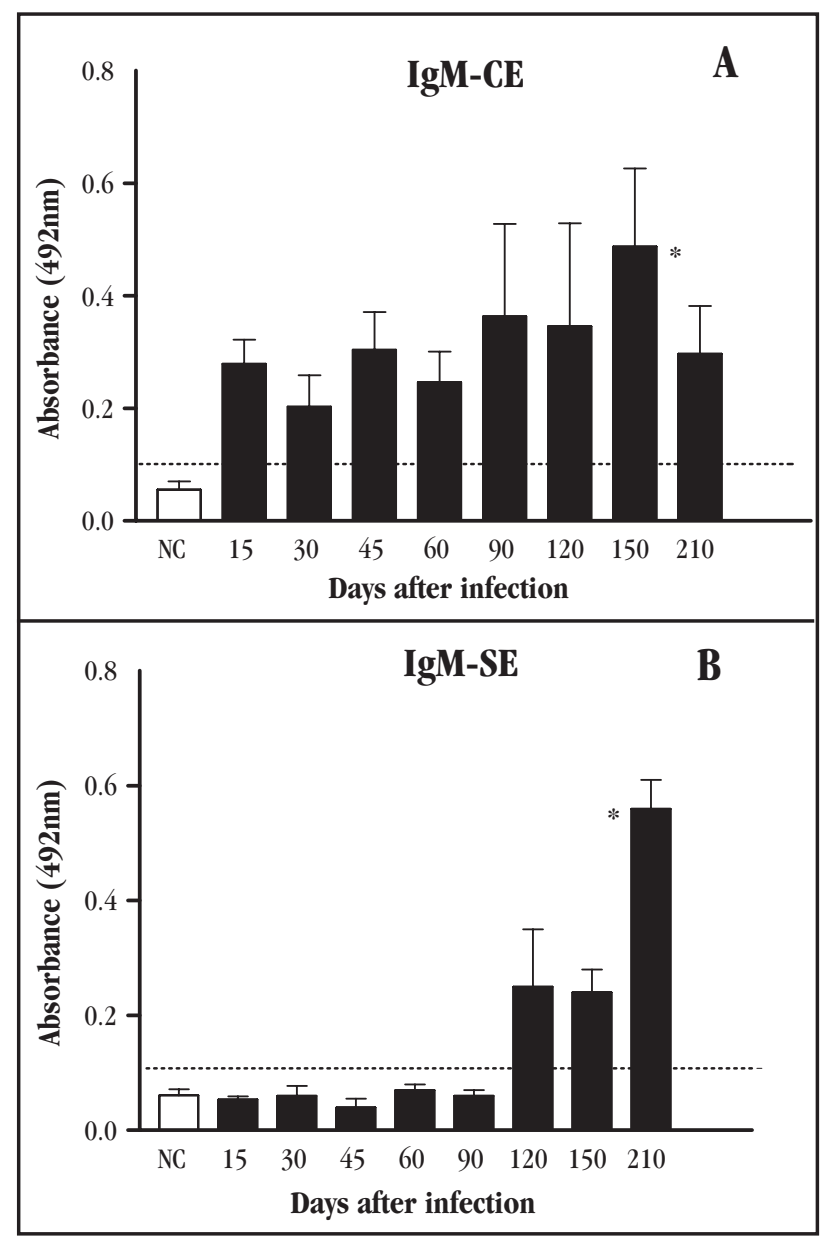

FIGURE 1

Kinetics of immunoglobulin M (IgM) isotypes according to ELISA in C57BL/6 mice without infection (NC-white bar) and with infection (black bar) with Lagochilascaris minor: (A) against the crude extract; (B) against the secreted/excreted antigen of the parasite. Dotted line represents the cutoff. Results are expressed as means for six mice \pm SD $(* \mathrm{p} \leq 0.05)$. 


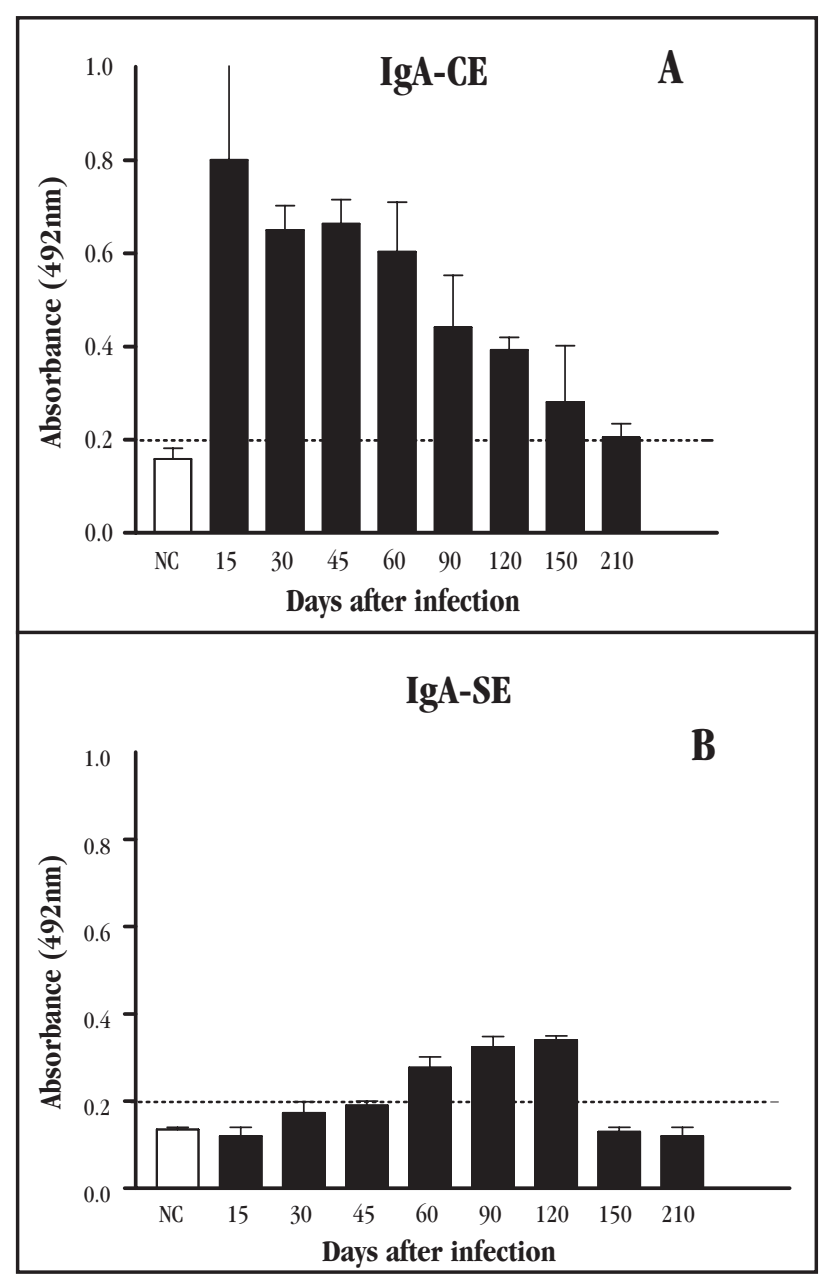

FIGURE 2

Kinetics of immunoglobulin $\mathrm{G}$ ( $\mathrm{IgG}$ ) isotypes according to ELISA in C57BL/6 mice without infection (NC-white bar) and with infection (black bar) with Lagochilascaris minor: (A) against the crude extract; (B) against the secreted/excreted antigen of the parasite. Dotted line represents the cutoff. Results are expressed as means for six mice \pm SD (*p $\leq 0.05)$.

no difference relating to sex. We found a marked difference in the pattern of the antibody response elicited in infected mice for both the crude extract and the secreted/excreted antigens of Lagochilascaris minor. The antibody levels for secreted/excreted antigen were always smaller.

IgM antibodies for anti-crude extract antigens were detected 15 to 210 days after infection in C57BL/6 infected mice (cutoff optical density $=0.1 \mathrm{~nm}$ ). Significant differences in optical density were only found for the serum collected 15 to 45 and 150 to 210 days after infection, but anti-secreted/excreted antigen antibodies were only detected 120 to 210 days after infection (cutoff optical density $=0.1 \mathrm{~nm}$ ) in infected animals (Figures 1A and 1B) with significant differences in optical density among the serum collected 150 to 210 days after infection.

On the other hand, when the crude extract antigen was used, the levels of IgA antibodies became positive 15 to 180 days after infection (cutoff optical density $=0.2 \mathrm{~nm}$ ), with statistical differences in optical density among serum collected 120 to 150 days after infection. However, C57BL/6 mice presented positive levels of IgA antibodies for secreted/excreted antigens of the

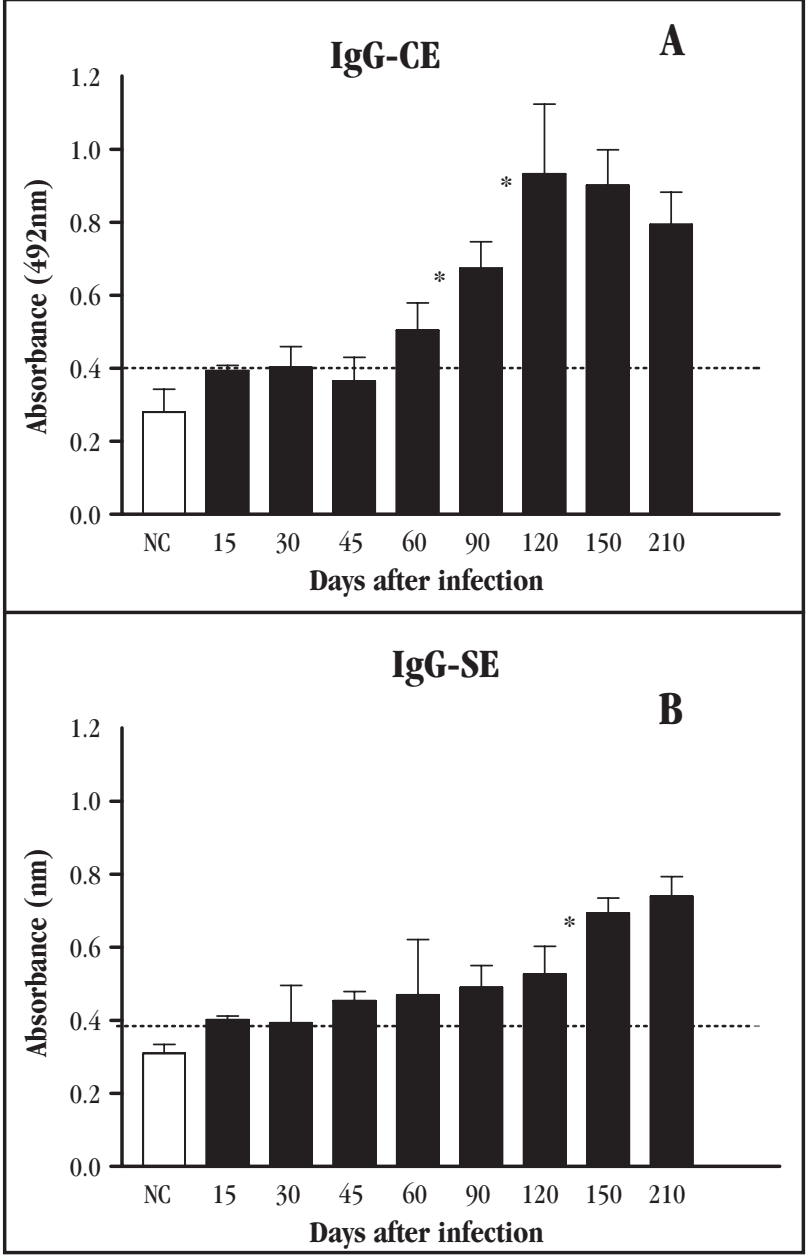

FIGURE 3

Kinetics of immunoglobulin A (IgA) isotypes according to ELISA in C57BL/6 mice without infection (NC-white bar) and with infection (black bar) with Lagochilascaris minor: (A) against the crude extract; (B) against the secreted/excreted antigen of the parasite. Dotted line represents the cutoff. Results are expressed as means for six mice \pm SD $(* p \leq 0.05)$.

parasite 45 to 120 days after infection (Figures 2A and 2B).

Specific IgG antibodies against crude extract were detected 60 to 210 days after infection (cutoff optical density $=0.4 \mathrm{~nm}$ ), with statistically differences in optical density among serum collected 60 to 120 days after infection, but $\mathrm{C} 57 \mathrm{BL} / 6$ infected mice presented a positive reaction against the secreted/excreted antigen (cutoff optical density $=0.4 \mathrm{~nm}$ ) 45 to 210 days after infection, with statistically differences in optical density among serum collected 120 to 150 days after infection (Figures 3A and 3B).

The levels of IgE antibodies were not determined.

\section{DISCUSSION}

B-cells play a fundamental role in host defense. They act as sentinels, by surveying the body for the presence of non-self antigens; as inducers of the immune response, by presenting antigens to antigen-specific T-cells; and as effector cells, by differentiating the producers of specific antibodies in plasma cells. The humoral immune response has been shown to provide 
an innate-like response involving B1 and spleen marginal zone cells, and an adaptive immune response involving conventional follicular B2-cells ${ }^{1}$.

IgM and IgA specific to the crude extract of Lagochilascaris minor appear early during experimental infection. B1 cells usually interact with antigens that present repetitive epitopes (TI-2), producing large amounts of $\operatorname{IgM}, \operatorname{IgA}$ and $\operatorname{IgG} 3^{11}$. Mice have been found to produce characteristic antibody responses: TI-2 (IgM), mediated by Th1 cells and IFNy (IgG2a); Th2 cells and IL-4 (IgE, IgG1); and Treg/Th17 cells and TGF $\beta(\operatorname{IgA})^{12}$.

$\mathrm{C} 57 \mathrm{BL} / 6$ mice were found to present constant positive levels of IgM against the crude extract throughout the study period. IgA presented higher levels at the start of the infection and decreased slowly after 90 days of infection. The delay in obtaining positive levels of IgG against the crude extract antigens of the parasite (60 days after infection) may reflect the time required for activation of $\mathrm{T}$ cells and generation of memory T cells and long-life plasma cells ${ }^{12}$.

The levels of IgA and IgM antibodies were the first ones to turn positive during the infection ( 15 days) and these remained positive throughout the study period, thus indicating the importance of IgM and IgA for detecting recent infection in rodents ${ }^{2}{ }^{10}$. It is important to remember that eosinophils present a receptor for IgA, which indicates that this isotype of immunoglobulin has early participation in allergy and helminth infections ${ }^{3} 8$.

IgA and IgM antibodies against the secreted/excreted antigen of Lagochilascaris minor became positive only for a short period, but IgG directed to secreted/excreted antigen appeared 45 days after infection. IgG antibodies against the crude extract became positive only after 60 days of infection, but may represent protector antibodies. It is important to determine the subclasses of specific $\operatorname{Ig} G$ during the experimental infection in mice, and we are now planning on analyzing the infection in mice pre-immunized with antigens of Lagochilascaris minor.

From a diagnostic point of view, the crude extract of Lagochilascaris minor may be considered the best antigen; detection of IgM and IgA alone may indicate recent infection; and detection of IgM and IgG may indicate chronic infection.

It is important not to neglect the participation of B cells in the evolution of infection and lesions, as well as in the diagnosis of experimental lagochilascariosis in mice and natural infection in other rodents.

\section{ACKNOWLEDGEMENT}

The authors would like to thank the Journal Experts for the English language review.

\section{REFERENCES}

1. Acosta-Rodriguez EV, Merini MC, Montes CL, Motràn CC, Gruppi A. Cytokines and chemokines shaping the B-cell compartment. Science Direct 18: 73-83, 2007.

2. Belkaid Y, Blank RB, Suffia I. Natural regulatory T cells and parasites: a common quest for host homeostasis. Immunogical Review 212: 287-300, 2007.

3. Bleay CP, Wilkes S, Paterson ME. Density-dependent immune response against gastrointestinal nematode Strongyloides ratti. International Journal of Parasitololy 37:1501-1509, 2007

4. Fraiha H, Leão RNQ, Costa FSA. Lagochilascariase humana e dos animais domésticos. Veterinary Interbational Zoonozes 1: 25-33, 1989.

5. Leiper RT. A new nematoda worm from Trinidad: Lagochilascaris minor. Proceeding of the Zoological Society of London 4: 742-743, 1909.

6. Oliveira JA, Barbosa CA, Vieira MA, Fiorini MO, Campos DMB. Isolado de Lagochilascaris minor: procedimentos para obtenção de ovos infectantes. Revista de Patologia Tropical 31: 121-128, 2002.

7. Paço JM, Campos DMB, Araújo de Oliveira J. Wild rodents as experimental intermediate hosts of Lagochilascaris minor Leiper, 1909. Memórias do Instituto Oswaldo Cruz 94: 441-449, 1994.

8. Pleass RJ, Lang ML, Kerr MA, Woof JM. IgA is a more potent inducer of NADPH oxidase activation and degranulation in blood eosinophils than IgE. Molecular Immunology 44: 1401-1408, 2007.

9. Riggs J, Howell K, Matechin B, Matlack R, Pennello A, Chiasson R. X-chromosomelinked immune-deficient mice have B-1b cells. Immunology 108: 440-451, 2003.

10. Sakaguchi S. Regulatory T cells. Immunological Review 212: 5-7, 2006.

11. Sakamoto T, Cabrera PA. Subcutaneous infection of Lagochilascaris minor in domestic cats from Uruguay. Veterinary Parasitology 108: 145-152, 2002.

12. Schimidt-Weber C, Akdis C, Akdis M. Th17 cells in the big picture of immunology. Journal of Allergy and Clinical Immunololy 120: 247-253, 2007.

13. Semerene AR, Lino-Junior RS, Oliveira JA, Magalhães AV, Stefani MMA, Barbosa AP, Campos DMB. Experimental lagochilascariosis: histopathological study of inflammatory response to larval migration in the murine model. Memórias do Instituto Oswaldo Cruz 99: 393-398, 2004.

14. Volcan GS, Medrano CE, Payares G. Experimental heteroxenous cycle of Lagochilascaris minor Leiper, 1909 (Nematoda: Ascarididae), in white mice and cats. Memórias do Instituto Oswaldo Cruz 87: 535-532, 1992. 